\title{
Improving Students Speaking Motivation by Using Role Play Technique at Institute Islamic in Indonesia
}

\author{
Paidi Gusmuliana ${ }^{1, *}$, Eka Apriani ${ }^{1}$ and Syafryadin ${ }^{2}$ \\ ${ }^{1}$ Institut Agama Islam Negeri (IAIN) Curup, Indonesia \\ ${ }^{2}$ Universitas Bengkulu, Indonesia \\ *Corresponding author. Email: paidigusmuliana@gmail.com
}

\begin{abstract}
The purpose of this paper was to investigate the problems that the students faced, because they were not willing to speak in particular English. Role play is known for being one of the best teaching techniques and can motivate students to talk. The aim of this paper was then to find out if there was any sign of the impact of Role Play on the motivation of learners to speak English. There are 60 students from the English Tadris study program at IAIN Curup were the subject of this research. In order to learn the motivation of students in the language course, the questionnaire was used. The results have shown that Role Play has a major effect on motivation in English speaking (t0: 4.342 > ttable: 2.65). The motivation of the students is higher in Experimental Group (70.20) than in the Control Group (60.10 percent). Finally, this technique has helped motivate the students to be more active in expressing their ideas spontaneously and naturally.
\end{abstract}

Keywords: Speaking, Motivation, Role Play Technique.

\section{INTRODUCTION}

Teaching speaking in the classroom is always expected to result in communicative activities that provide an opportunity for a personal relationship to develop both among learners and between learners and lecturer. Communicative activities or we called it a conversation. Conversation is one of the things students are doing with their lives. [1]. The relationship creates a situation that brings learners to be involved, supporting their efforts marked with activating oral ability to communicate ideas of what the topic is being discussed.

Speaking as the first manifestation of language has been positioned as an importantly considered skill that should be taught with the appropriate technique. Communicative efficiency as the goal of teaching speaking is a target that should be achieved. The achievement of the target involves cooperation in both teacher and students in which the teacher not only knows what to do in teaching speaking but also gives motivation and even awareness for the students about how important the subject is. The techniques used in teaching speaking determine the success of the teaching which should always be conditioned with the students' ability, so that the students will seriously feel guided and joyful, really bringing them more interested and confident in expressing their ideas. Of course, inhibition, fear of making mistakes, keeping silent, or other speaking problems can be avoided. When teachers enable their students to be communicatively competent in English as a foreign language or a second language, a significant part of the overall competence of the teacher is taken into account [2].

The skilled teacher in selecting techniques and supported strategies can also help the students do more to make them easy to apply their strategies for the techniques applied so that what has been targeted is successfully achievable. An appropriate technique or strategy used by English teachers can improve students' achievement [3]. Zainil [4] suggests "a language teacher must identify their students' learning strategies and recognizes that some strategies are successful and others unsuccessful." It indicates that the teacher also has a role to help the students recognize what the appropriate strategies suitable for them are. It is due to the inability of the students to find their strategies and how to use them. Furthermore, Harmer [5] discuss some important points of developing learning strategies that can help students become effective learners with a variety of tools in all types of learning and understanding. Firstly, Teachers have to point out that the strategies learned can 
help not only in language but also in other subject areas and even in any situation that understanding is needed.

Secondly, Teachers should explicitly discuss why and how each strategy can improve students' understanding, production, and learning. Thirdly, the Teacher needs to build students' metacognitive knowledge that consists of work, not for the students, the teacher can encourage them to use others. Furthermore, Ellis [6] explains the ways or strategies that should be taken by the teacher in solving the speaking problems that make the students able to improve their speaking skill that involves: use group work, focus the activity on simple word, pay attention to the subject and assignment to generate interest, include some discussion skills guidance or preparation, and keep students speaking the target language.

On another side, the application of techniques is also more importantly viewed as a crucial medium is separated from the success of teaching speaking. The techniques will work for hand in hand with strategies in improving the students' ability in speaking. On the other hand, the techniques can not work alone. Thus, the techniques applied are well- considered to be selected based on what the students need. In this case, the teacher will show his role of it because the wrongly selected techniques will be influential for the students. Therefore, the teacher is expected to have various techniques in teaching speaking. Ur [7] views that various techniques for stimulating speaking or conversation are intended to help and lead students into a more advanced dimension that reflects their progress in English such as: directing conversation sessions, dialogues, improvisations, plays, speeches, small- group discussion, debates, motion picture, cultural orientation, proverbs, humor, songs, poetry, correspondence, group project, field trips, and games. Dobson [8] founds that the learning language environment can affect students' speaking ability. In the same case, [9], [10], [11], and [6] support theories and accept that certain kinds of strategies are used to develop students' speech skills and inspiration, such as role-playing, modeling, oral reporting, debate, etc. The purpose of various techniques in teaching speaking refers to communicative efficiency as explained in the previous statements.

Furthermore, based on the preliminary research that the researcher interview some students in speaking class at the first semester of English Departement in IAIN Curup, a great number of them answer that they were afraid and felt shy to begin a conversation or to practice English with their lecturer and classmates. Many of them had a good ability in speaking English, but they were reluctant to express their idea. So, to minimalism this insufficiency, the lecturer needed such techniques as to how to motivate the students in order they could speak up. The successfully chosen technique used to achieve communicative efficiency will put the students into a more communicative environment of speech that results in an interaction. It means that students are more secure in speaking, voicing ideas more instinctively and spontaneously based on the context, not neglecting, of course, the other essential aspects of the speech itself. Besides, students will feel free to construct an oral form for the expression created. One of the approaches, called the Role Play Strategy, is worth trying to make our aim come true. This paper aims to convey a technique called Role Play that is deemed skilled to enhance motivation for speaking and also completed with substantial details and ways of applying this technique.

\section{THEORETICAL FRAMEWORK}

\section{Motivation in Teaching Speaking}

Motivation is one of the key things that can inspire students to speak English, and teachers' fans can help encourage students to speak English. Any descriptions of the motivation of the experts are: motivation is some sort of internal intensity, according to Harmer [9], which drives someone to do something to accomplish something. To do something, motivation is an important part of doing things. Malley [12] mentions that motivation is effort, desire, a learning attitude. Motivation is the ability to put a great deal of work into the organizational goals, conditioned on the potential of the effort. To serve any individual need. The motivated person, as Gardner has suggested, is one who wants to achieve a specific goal, makes substantial efforts to achieve that goal, and experiences satisfaction with the activities associated with achieving that goal. Motivation is one of the factors influencing individuals to learn a language effectively. In other words, the outcome of learning would be higher if the incentive is greater. Motivation has been known to be a sequence and converted into the action of thoughts, feelings, and emotions. Motivation is the primary factor in the speed and productivity of language analysis. The first impetus is to be inspired to learn a language as the encouragement would add feelings of happiness to the students, an obstacle to success in learning the language.

There are some behavioral markers of students with high motivation [13]:

1. Students who are inspired to attend class at the most basic stages, pay attention, and are not disruptive;

2. Participation and completion of motivated work begins with little feedback, follow the guidance, take part in class discussions and perform the complete task in due course;

3. Persistence of tasks and mistake acceptance. A significant measure of motivation is how long 
students stay with an assignment, particularly a difficult one. Students with a high degree of commitment persist and find multiple strategies before searching for assistance with a mission.

4. Mission participation performance. Students may either spend time studying or find shortcuts to complete the task without spending a lot of time. A fundamental indicator of motivation is the amount and quality of effort that students spend on learning activities. Highly motivated students can spend time using their skills.

5. Individually studying. Even if it is time to step onto something else, students who can learn more than possible are reluctant to stop working on a mission. You can also bring home equipment, complete non-purchased work, or ask questions about a subject.

The writer agrees with both of these claims that inspiration is a good incentive for language education to achieve the purpose of the foreign language. Meece [14] stated some significant motivational factors:

a. Home care and friends support. Family and friends' actions may have an important effect on children's motivation. If their parents and peers encourage them to learn, they are more likely to be positive about learning. Home aid is an important part of the promotion of foreign language learners.

b. Transfer energy. Move capacity. Students who can change what they will learn in various ways would be more motivated by the new knowledge they have learned than those who do not search and understand.

c. The self-awareness. To encourage students to learn actively, they need to see themselves as successful. In a particular example, expectation and the importance of this achievement determine the strength of motivation.

d. The absence of an intrinsic incentive. Intrinsic motivation is encouraged by the sense of accomplishment resulting from coping with something that was originally a little challenging. Rewards are meant to inspire children to learn, not to meet domestic goals to achieve the rewards. Incentives may also hurt motivation.

e. The assessment and risks. If children expect to be tested, feel disadvantaged or feel observed and controlled, they are likely to study for appraisal reasons, escape discipline or alleviate the supervision of adults and lose all inner desire to learn.

f. Social identification (Peer group). It seems that their peer groups have been quite influenced by students. In interacting with the students and building a positive image of competence in a foreign language, it is necessary to bear these peer pressures in mind. The interactions of the students with their peers are an important part of the learning process.

g. The environment of Learning. For learners to be encouraged, the learning environment must be free from fear; students should not be harassed or intimidated. Students must know that he/she will be heard so that what she/he says will be worth hearing.

According to Stipek [15], Incentive Motivation Psychology (IMP), a concept chosen to characterize the implicit relationship between "incentive" and "motivating," included a deliberate educational strategy via a scheme of intrinsic and extrinsic incentives to induce particular learner performance. Brewer and his colleagues observed that the first and most popular form of IMP was intrinsic reinforcement (IIM, an incentive method derived from the reward scheme itself) The external reinforcement of IMP (EIM) has shown the essential connection between learning and an external reward scheme. The value of IIM and EIM for improving student success and improving learning motivation is clear, though there is a possibility that there will be some doubt about the utility of IMP, the authors concluded. Incentive program preparation and implementation are relatively easy until educators decide which form is best for the needs of students. In addition to the lecture, Brewer [16] presented the following teaching strategies and Role Play technique can sustain student interest, helping to improve student motivation and performance.

\section{Role Play Technique}

Some experts clarify the mechanism of role play. Brewer [17] Role Play is perfect to talk in a reasonably healthy atmosphere in the classroom. Students in a roleplay include special responsibilities in the destination language and experience in a true setting in speaking the target language. In certain instances, it helps individuals to become agile and to establish a sense of superiority. It is one of a wide range of Communication techniques that enhance the fluency and encouragement of language learners. Roleplay is an adequate method to enhance the communication skills of students and to increase their excitement by providing a role. Role play includes: (a) assigning one or more members of a group to the purpose or purpose that participants need to accomplish in Huang [18], and (b) assigning them a role. The recommended task can be played by a single person, in a pair or a group, and each person will have a role in achieving an objective. Play role lets students appreciate and benefit from their role-playing experience. By using Role Play, learners can:

1. A sense of superiority can be established in many situations.

2. Improve your capacity to communicate and speak in general. 
3. Show your ingenuity and build your imagination.

4. Improve cognitive skills, communicate with others and enhance linguistic progress in general. Students should share their responsibilities and responsibility.

Then Brewer [17] playing roles as an education tool gives students several advantages:

1. Increasing student motivation;

2. Development of student creativity;

3. Enjoyable for students;

4. As involved students, students become. Increased learning benefits from participation;

5. Improving social understanding, critical thought and viewpoint verbalization,

6. teaches empathy and comprehension of diverse perspectives,

7. It enhances communication and interpersonal skills, as well as communication skills and;

8. Students could communicate their being, humor, and personal style of communication.

The author uses the Huang Y technique. Unwritten role-playing is required. Students don't depend on textbooks, therefore. This is a free role-play. Students must decide what words they are using and how they can start communicating. Good teacher and student preparation are really important for this operation.

Play of roles refers to speech activities that promote collaboration, encourage involvement, and inspiration. According to [19], Roleplay is one of a whole range of communication strategies that enhances the fluency of language learners, fosters engagement in the classroom, and motivation. The role-playing is increasing student interest in learning English and enhances student motivation to speak, according to [20]. Role plays, drama activities, and games will boost learners' trust in their oral communication ability and will develop simulations and organized communication exercises. The author concludes that role play will increase the motivation of students to speak English based on the meanings of the experts.

\section{RESEARCH METHODOLOGY}

The design of this analysis was an almost experimental design that used the non-equivalent design of the control group. The aim of this analysis was to evaluate the effect on motivation from the use of roles. This study covered two groups. There was one study group and another monitoring group. The study group was treated by Role Play and the control group was not treated by Role Play. This analysis contained two variables, one being an independent variable, the other being a dependent variable (motivation of students in speaking English). The author used the intact group as the sampling technique where the number of therapy classes was 30 at the same time as the number of control classes, 30 students. The subject of this research is 60 students of the English Tadris Study Program in IAIN Curup.

Then the tool used to collect the data was a closeended questionnaire that used the Likert Scale with scores ranging from 1 to 5 in which Often (5), Sometimes (4), Often (3), Seldom(2) and Never(1) have an alternative response for of argument. After learning the Speaking with the Role Play process, the questionnaire was distributed to each respondent about their motivation. Then the technique of data analysis in the form of hypothesis testing using T-test helps by using SPSS to know if the use of role-play technique has a major impact on the motivation of the students in Learning Speaking.

\section{RESULTS AND DISCUSSION}

The author found the answers to three questions about the formulation of the issues. To discover the results of the analysis we need to assess and quantify the gain of the outcome of the pre-questionnaire before and after the procedure. The following table shows the description and percentage of the incentive of students to learn to speak as in the following Tables 1 and 2:

Table 1. The Classification of Students' Motivation in Speaking Score

\begin{tabular}{|c|c|c|}
\hline No & Categories & Score \\
\hline 1 & Very Strong & $81 \%-100 \%$ \\
\hline 2 & Strong & $61 \%-80 \%$ \\
\hline 3 & Enough & $41 \%-60 \%$ \\
\hline 4 & Low & $21 \%-40 \%$ \\
\hline 5 & Very Low & $0 \%-20 \%$ \\
\hline
\end{tabular}

Table 2. Students' Speaking Motivation in Control and Experimental Group

\begin{tabular}{|c|c|c|}
\hline \multicolumn{3}{|c|}{ and Experimental Group } \\
\hline Group & Before & After \\
\hline Control & 57.10 & 60.10 \\
\hline Experiment & 57.27 & 70.20 \\
\hline
\end{tabular}

The collected data were then computed from the table above by the following calculation to obtain the score and its percentage (Control= 57.10\%, Experimental Group $=57.27 \%$ ). From the percentage above, it can be concluded that the motivation of the students to speak English before using Role Play was Enough. The collected data was then determined from 
the above table by the following equation to obtain the score and its percentage (Control 60.10\%, Experimental $70.20 \%)$. From the percentage above, it can be inferred that the motivation of the students was high after using Role Play to speak English (Strong Motivation).

The following Table 3 explains both the experimental and control classes' pre-questionnaire and post-questionnaire score data. It was derived from the results of the motivation questionnaire for the students. It defines the data as follows:

Table 3. Students' Motivation in Speaking English in Experimental and Control Class

\begin{tabular}{|c|c|c|c|c|c|c|}
\hline \multirow{2}{*}{$\begin{array}{c}\text { Stude } \\
\text { nts }\end{array}$} & \multicolumn{2}{|c|}{ Experiment } & & \multicolumn{2}{|c|}{ Control } & \multirow{2}{*}{ Gain } \\
\cline { 5 - 5 } & Pre & Post & Gain & Pre & Post & Gain \\
\hline Total & 1718 & 2106 & 388 & 1781 & 1939 & 158 \\
\hline Mean & 57.27 & $\begin{array}{c}70.2 \\
0\end{array}$ & 12.93 & $\begin{array}{c}59.3 \\
7\end{array}$ & 64.63 & 5.27 \\
\hline
\end{tabular}

Based on the above Table 3, it was clear that students were more inspired to speak English in the experimental class than students in the control class. From the computation, it can be shown that $12.93>$ 5.27. This means that the first semester of the IAIN Curup English Study Program has a major impact on motivation by using Role Play in speaking English.

Table 4. Independent Samples Test

\begin{tabular}{|c|c|c|c|c|c|c|c|c|}
\hline \multicolumn{2}{|c|}{$\begin{array}{l}\text { Levene's } \\
\text { Test for } \\
\text { Equality } \\
\text { of } \\
\text { Varianc } \\
\text { es }\end{array}$} & \multicolumn{7}{|c|}{ t-test for Equality of Means } \\
\hline \multirow[b]{2}{*}{$\mathrm{F}$} & \multirow[b]{2}{*}{ Sig } & \multirow[b]{2}{*}{$\mathrm{t}$} & \multirow[b]{2}{*}{ df } & \multirow{2}{*}{$\begin{array}{l}\text { Sig. } \\
(2- \\
\text { taile } \\
\text { d) }\end{array}$} & \multirow{2}{*}{$\begin{array}{l}\text { Mean } \\
\text { Differen } \\
\text { ce }\end{array}$} & \multirow{2}{*}{$\begin{array}{l}\text { Std. } \\
\text { Error } \\
\text { Differen } \\
\text { ce }\end{array}$} & \multicolumn{2}{|c|}{$\begin{array}{l}95 \% \\
\text { Confidenc } \\
\text { e Interval } \\
\text { of the } \\
\text { Difference }\end{array}$} \\
\hline & & & & & & & $\begin{array}{l}\text { Low } \\
\text { er }\end{array}$ & $\begin{array}{l}\text { Upp } \\
\text { er }\end{array}$ \\
\hline $\begin{array}{l}9.93 \\
0\end{array}$ & $\begin{array}{l}.00 \\
3\end{array}$ & $\begin{array}{l}4.34 \\
2 \\
4.34 \\
2\end{array}$ & $\begin{array}{l}58 \\
43.7 \\
54\end{array}$ & .000 & 5.567 & $\begin{array}{l}1.282 \\
1.282\end{array}$ & \begin{tabular}{|l}
3.00 \\
1 \\
2.98 \\
3
\end{tabular} & $\begin{array}{l}8.13 \\
3 \\
8.15 \\
1\end{array}$ \\
\hline
\end{tabular}

It can also be seen from the Table 4 above that t 0 is (4.342) and $\mathrm{df}$ is 58 . Because $\mathrm{df}=58$ was not found from the table, $\mathrm{df}=60$ was taken by the researcher, t0 was compared to either 5 percent or 1 percent at the stage. At the $5 \%$ table level, it is 2.00 , and at the $1 \%$ table level, it is 2.65 . Based on the table, it can be analyzed that $\mathrm{t} 0$ is either at level $5 \%$ or $1 \%$ higher than the table. In other terms, $4.342>2,65$ can be inferred. It says that the hypothesis of null (Ho) has been overturned and the hypothesis of alternative (Ha) accepted. That means that Role Play has a major influence in the first half of IAIN Curup English.

As a consequence of data analysis, the use of roleplaying methods has helped to improve the incentive of students to speak English. The effectiveness of Role Play from the t-table above indicates that the value of the t-test was greater than the value of the t-table. It implies that after treatment there was a major impact, so the incentive of the students to speak English was effective as a source of material in teaching the speech of students. Overall, by using the role-play technique, the participant of the students improved, most of them were active to talk and had conversations between them and the lecturer. In teaching speaking, the use of the Role Play technique was successful in motivation.

Some comments confirmed the previous researcher Shen [21] that role-playing offers students certain experiences to see that they perform their role specifically in English communication and that students have exercised speech skills in front of their peers and have improved confidence throughout the classroom. Brewer [17] said the roleplay also offers a real-life setup and allows students to communicate freely and confidently in their friend's classroom and also to make contact between classrooms enjoyable, desirable and safe. Finally, Brewer [17] said that role-playing could make the students more positive and not frightened of error. Together with some earlier facts, the scientist believes the role of students in speaking English has improved their motivation. To sum up, the researchers affirmed that counseling through the role-played method was helpful in increasing students' drive to speak English during the first semester of the English Study programme, in IAIN Curup.

\section{CONCLUSION}

Based on the findings and discussion above, the conclusions of this study were:

1. Students' Speaking Motivation in Control Group was $57.10 \%$ (pre-test) and $60.10 \%$ (post-test). It means that students' speaking motivation in the Enough Category.

2. Students' Speaking Motivation in Control Group was $57.27 \%$ (pre-test) and $70.20 \%$ (post-test). It 
means that students' speaking motivation Strong Category when using role-play in speaking class.

3. The Gain of the experimental group and control group were 12.93 and 5.27. 12.93 is greater than $5.27(12.93>5.27)$. It means that there is an impact on motivation by using Role Play in speaking English.

4. The result shows that $\mathrm{T} 0$ is higher than the table. In other terms, $4.342>2.65$ can be inferred. It means that H0 Rejected and Ha accepted.

\section{ACKNOWLEDGMENT}

This research was funded by the researchers themselves. The researchers want to thank all people who have supported in terms of psychology and motivation.

\section{REFERENCES}

[1] Syafryadin, Wardhana, and Apriani DEC. "Noermanzah, "Maxim Variation, Conventional, and Particularized Implicature on Students' Conversation", International Journal of Scientific and Technology Research, Vol.9, N0.2, 2020.

[2] Syafryadin, H., \& Salniwati, A. R. A. P, "Digital Storytelling Implementation for Enhancing Students' Speaking Ability in Various Text Genres", 2019.

[3] Apriani, E, "Using The Think-Pair-Share (TPS) Strategy to Enhance Students' Reading Achievement of The Seventh Grade at MTsN Lumpatan", Belajea; Jurnal Pendidikan Islam, Vol.1, N0.2, 2016.

[4] Zainil, "Actional and Functional Model: Good Language Learner Strategies and Communicative Language Teaching (2nd)", Padang: Sukabina Offset, 2008.

[5] Harmer, J, "The Practice of English Language Teaching”, New York: Longman Press, 1985.

[6] Ellis, G, Sinclair, "Learning to Learn English", Cambridge: Cambridge University Press, 1989.

[7] Ur, Penny, "A Course in Language Teaching". Cambridge: Cambridge Press, 1996.

[8] Dobson, M. J., "Effective Techniques for English Conversation Groups". Washington D.C: English Language Program Division Bureau of Educational and Cultural Affairs United States Information Agency, 1981.

[9] Apriani, E., Anshori, S., \& Edy, S, "Eksistensi English Zone Sebagai Media Penerapan Kemampuan Berbahasa Inggris Mahasiswa Program Studi Tadris Bahasa Inggris IAIN CURUP", Cendekia: Jurnal Kependidikan Dan
Kemasyarakatan, Vol 17, No.2, Page.317-332, 2019.

[10] Harmer, J, "The Practice of English Language Teaching”, Third Edition. London: Longman, 2007.

[11] Weir, J. C, "Understanding and Developing Language Tests”, New York: Prentice-Hall, 1993.

[12] Malley, M. J, Pierce, V. L, "Authentic Assessment for English Language Learners", Virginia: Addison- Wesley Publishing Company, 1995.

[13] Dornyei, Zoltan, "Teaching and Researching Motivation: Second Edition", Great Britain: Pearson Education Limited, 2001.

[14] Meece, Judith, Wendy McCloskey., "Improving Students Motivation: A Guide for Teachers and School Improvement Teams, Third Printing". Greensboro: University of North Carolina, 2001.

[15] Stipek, D, "Motivation to Learn: From Theory to Practice". Englewood Cliffs, NJ: Prentice-Hall, 2001.

[16] Brewer, E. W., Dunn, J., \& Olszewski, P, "Extrinsic reward and intrinsic motivation: The vital link between classroom management and student performance", 1988.

[17] Brewer, E. W., Hollingsworth, C., \& Campbell, A, "Incentive motivation psychology: An exploration of corrective learning behavior", Journal of the Southeastern Association of Educational Opportunity Program Personnel, Vol.14, No.1, Page. 33-56, 1995.

[18] Y. Huang, Irene, "Role Play for ESL/EFL Children in English Classroom”, The Internet TESL Journal. Taiwan: National Cheng Chi University, 2007.

[19] Brown, H. Douglas, "Principles of Language Learning and Teaching”, Taiwan: Taiwan National Cheng Chi University, 2008.

[20] Ladousse, "Role Play for ESL/EFL Children in the English Classroom", Taiwan: National Cheng Chi University, 2008.

[21] Shen, Lin, and Jitpanat Suwanthep, "E-Learning Constructive Role Play for EFL Learners in China's Tertiary Education", Asian EFL Journal, Vol. 54, 2011.

[22] Kusmana, Andi, "The Influence of Role Play and Drills in Stimulating Students' Motivation for learning English Conversation at the First Grade of SMP Darussalam Jakarta Selatan", Universitas Jakarta: Unpublished Thesis, 2011. 